\title{
Facilitating Oak and Hickory Regeneration in Mature Central Hardwood Forests
}

\author{
Eric J. Holzmueller *, John W. Groninger and Charles M. Ruffner \\ Department of Forestry, Southern Illinois University, 1205 Lincoln Drive MC 4411, Carbondale, \\ IL 62901, USA; E-Mails: groninge@siu.edu (J.W.G.); ruffner@siu.edu (C.M.R.) \\ * Author to whom correspondence should be addressed; E-Mail: eholzmue@siu.edu; \\ Tel.: +1-618-453-3708; Fax: +1-618-453-7475.
}

External Editor: Eric J. Jokela

Received: 26 November 2014; in revised form: 10 December 2014 / Accepted: 15 December 2014 / Published: 19 December 2014

\begin{abstract}
Advanced oak and hickory regeneration is often absent in mature oak-hickory forests in the Central Hardwood Region of the United States. Prescribed fire and thinning, alone and combined, are commonly prescribed silvicultural treatments that are recommended to initiate the regeneration process. This study examined the regeneration response in three mature oak stands following four treatments: (1) thin, (2) burn, (3) thinning and burning, or (4) no treatment (control). Ten years after initial treatment, results indicate that oak and hickory seedlings had greater height and diameter in the thinning and burning treatment compared to the control and that this treatment may help facilitate desirable regeneration in mature oak-hickory forests.
\end{abstract}

Keywords: Quercus; Carya; prescribed fire; timber stand improvement

\section{Introduction}

Management for ageing oak-hickory (Quercus-Carya) forests within the Central Hardwood Region of the United States often entails a balance between achieving regeneration while maintaining mature forest structure. When canopy replacement does inevitably occur, shade-tolerant, mesophytic tree species that are established either prior to or immediately following disturbance capture site resources and decrease oak dominance in the next stand [1]. In addition to broad-scale climate shifts, ascendance 
of mesophytes at the expense of oaks and hickories has been widely attributed to land use practices and game management policies over the past several decades that together contribute to oak regeneration [2-5].

Silviculturists now recognize that in order to secure oak regeneration on sites of moderate productivity, large canopy disturbances must be preceded by sub-canopy disturbances [6,7]. Accordingly, some public land managers and stewardship programs for private lands have initiated programs to increase oak regeneration [8]. Prescribed burning and thinning are activities that are often associated with these programs.

In southern Illinois, and throughout much of the Central Hardwood Region, maintaining an open forest understory, whether by fire, thinning or both, is consistent with land stewardship ethics, ownership objectives and esthetic sensibilities held by some $[9,10]$. In 2002, a consortium of state forest management personnel, private forest landowners, and university researchers established a series of plots to assess the long-term impacts of light thinning and prescribed fire consistent with those forest stewardship management practices. The objectives of this paper were to compare regeneration of overstory tree species in response to fire and thinning, alone and in combination, compared to an untreated control. While similar studies have examined the results of these treatments $[7,8,11,12]$ our paper is unique in that it does not involve an initial commercial harvest, has multiple burns, separates hardmast species by groups (white oaks, red oaks, and hickory), and occurs 10 years after initial treatments. In particular, the amount of time following treatment (10 years) will help researchers to determine how long the effects of these treatments may last.

\section{Experimental Section}

\subsection{Study Site}

This study was conducted within the Shawnee Hills region of southeastern Illinois in Pope County. Three forested sites were selected and on each site slope ranged from $5 \%-25 \%$, aspect ranged from $90^{\circ}-270^{\circ}$, and elevation ranged from $100-200 \mathrm{~m}$ [13]. The sites were separated by $5-16 \mathrm{~km}$. One site was located on private property and two sites were located on State-owned public demonstration areas. Mean annual precipitation in the area is $122 \mathrm{~cm}$ and mean temperature is $21{ }^{\circ} \mathrm{C}$, over a 189-day growing season. Soils on the sites are dominated by well-drained silt loams (Wellson-Berks complex, mesic ultic hapludalfs and mesic typic dystrudepts, respectively) and site index ranges from 18-24 m for upland oak (base age 50).

Prior to treatment, all sites were dominated by mature ( $\sim 100$ years old) [14] oak and hickory trees in the overstory and ash (Fraxinus spp.) and elm (Ulmus spp.) in the understory (Carril 2009). On each site a 1.6 ha area was selected for topographic and stand structural uniformity, divided into 0.4 ha (square) units, and randomly assigned one of four treatments: (1) thin, (2) burn, (3) thinning and burning, or (4) no treatment (control). Thinning treatments removed all trees $<20 \mathrm{~cm}$ at diameter at breast height (except individuals of species that produce hard mast, e.g., oaks and hickories) in 2002 and resulted in an estimated reduction of $20 \%-30 \%$ of the original basal area [13]. Stumps were treated with Garlon 4 herbicide, (Triclopyr-61\% a.i.) immediately following cutting. Prescribed burning treatments were applied in the growing season (spring) of 2002 and 2006 and were low- to 
moderately-intense surface fires [13]. These thinning and burning treatments led to similar overstory basal area among all treatments and lower overstory stem density in the thin and thinning and burning combined treatments at the time of data collection (Table 1). Overstory oak and hickory comprised $>86 \%$ of basal area throughout all treatments. In terms of density, these species accounted for $48 \%$ of total stem density in the control compared to $63 \%-74 \%$ of stem density in the treated stands.

Table 1. Mean (S.E.) of overstory basal area, stem density, and stocking by treatment of the three forested stands used in this study. Stocking was calculated using Gingrich [15] upland stocking guide. Means are post treatment and were separated by Tukey option for post-hoc comparisons when ANOVA revealed a clear difference between treatments $(P<0.05)$.

\begin{tabular}{cccc}
\hline Treatment & Basal Area $\left(\mathbf{f t}^{2} / \mathbf{a c}\right)$ & Density (stems/ac) & Stocking (\%) \\
\hline Control & $104(11) \mathrm{a}$ & $160(14) \mathrm{a}$ & 90 \\
Burn & $113(10) \mathrm{a}$ & $155(7) \mathrm{a}$ & 95 \\
Thin & $105(18) \mathrm{a}$ & $90(10) \mathrm{b}$ & 82 \\
Thinning and Burning & $74(11) \mathrm{a}$ & $102(9) \mathrm{b}$ & 63 \\
\hline
\end{tabular}

Means followed by same letters do not differ significantly $(P<0.05)$.

\subsection{Data Collection and Analysis}

In 2012, 16 understory plots, 0.0004 ha (1.13 m plot radius), were established within each treatment unit at each site to determine differences in overstory species regeneration response among treatments. Plots were equally distributed within each unit in a grid format at least $25 \mathrm{~m}$ from treatment edge. At each plot, the tallest white oak (Quercus alba), red oak (typically Q. rubra or Q. velutina), hickory (Carya spp.), sassafras (Sassafras albidum), and of any other species was identified, and height (m) and diameter at root collar $(\mathrm{cm})$ of these understory seedlings was recorded. Only large seedlings $(>0.20 \mathrm{~cm}$ in height) were considered for this analysis. In addition, the total density of large seedlings was also recorded. Leaf area index (one sided green leaf area per unit ground area, LAI) was measured in each understory plot using hemispherical photography. A tripod with self-leveling camera mount was used and the camera placed above the seedling layer in each plot. Photographs were edited and analyzed using WinSCANOPY ${ }^{\circledR}$ to determine a value for LAI.

Data were analyzed for differences in the four treatments (thin, burn, thinning and burning, and control) for the following response variables: LAI, height and diameter of the tallest understory white oak, red oak, hickory, sassafras, and other species and total seedling density by species class. All response variables were analyzed with analysis of variance (ANOVA) using the Mixed procedure in SAS (SAS 2014). A mixed model ANOVA was used, wherein site (random effect) was nested within treatment. The sample size $(\mathrm{N})$ for the mixed model ANOVA was 12 (number of treatments $\mathrm{x}$ sites). When ANOVA revealed a clear difference between treatments $(P<0.05)$, we used the Tukey option for post-hoc comparisons. The relationship between LAI and height and diameter of the tallest white and red oak was tested using regression analysis. 


\section{Results}

Thinning and burning combined was the only treatment where red oak and white oak height and diameter of the tallest seedlings was significantly greater $(P<0.001)$ than in untreated controls or burning alone (Table 2). For red and white oak, thin alone was not significantly greater than burn alone or control but it was nominally greater showing some indication of improvement but with much variability in response. Thinning and burning together had almost three times more white oak regeneration density (all large seedlings $>0.20 \mathrm{~cm})$ compared to untreated $(P<0.05)$ while no differences were observed among treatments for red oak regeneration stem density $(P=0.25)$. Hickory height of the tallest seedlings was responsive $(P<0.001)$ to both thin only and thinning and burning treatments compared to the control and burn only. In contrast, only hickory diameter of the tallest seedlings in the combined thinning and burning was greater than the untreated control. Sassafras did not show a significant response to thinning or burning treatments compared to untreated controls $(P>0.11)$. The 'other' species observed were primarily Fraxinus spp. and Ulmus spp. (Table 3). Height and diameter of the tallest seedlings of these species were generally lower in the burn treatment and similar results were observed among other treatments. No difference was observed in stem density of the large seedlings $(>0.20 \mathrm{~cm})$ among the other species $(P=0.98)$.

LAI values varied slightly among treatments $(P<0.001)$. LAI was greatest in the untreated control (2.37) and least in thin only (1.75) with both burn treatments having intermediate values (1.98-2.06). There was no significant relationship between LAI and any of the response variables based on regression analysis $(P>0.5)$.

\section{Discussion}

The applied treatments appeared to significantly affect the development of white and red oak and hickory regeneration. The largest oak and hickory stems had over twice the height and diameter in the combined thinning and burning treatment compared to the control treatment. Thin or burn treatments alone did not result in larger oak stems compared to the control. Hickory height and diameter was greater than the control treatment in the thin treatment. Numerous studies have investigated the effects of prescribed fire on oak regeneration [8]. Generally, they indicate that burning alone does not facilitate oak regeneration in mature oak stands [12,16], although there are exceptions, particularly on xeric sites [17]. Studies that investigate the effects of thinning from below and fire are not as common although our results are similar to those of [11] who reported that a combination of these treatments is necessary to best facilitate oak regeneration.

The development of advanced regeneration has been associated with eventual oak dominance in Central Hardwood Forests [18]. Accordingly, the combined fire and thinning treatment increases the likelihood of successful oak regeneration with these treatments. Additionally, the combined fire and thinning treatment increased the relative abundance of white oak (compared to the control and sassafras) further increasing the potential for successful regeneration. 
Table 2. Mean (S.E.) height and diameter (of the tallest seedlings) and density of all large seedlings ( $>20 \mathrm{~cm}$ in height) by species class and treatment. Means were separated by Tukey option for post-hoc comparisons when ANOVA revealed a clear difference between treatments $(P<0.05)$ for each species class and treatment.

\begin{tabular}{|c|c|c|c|}
\hline Species Class & Height (m) & Diameter $(\mathrm{cm})$ & Density (stems/ha) \\
\hline \multicolumn{4}{|l|}{ White oak } \\
\hline Control & $0.16(0.04) b$ & $0.19(0.05) b$ & $2552(549) \mathrm{b}$ \\
\hline Burn & $0.17(0.03) \mathrm{b}$ & $0.19(0.03) b$ & $5469(1271) a b$ \\
\hline Thin & $0.23(0.05) \mathrm{ab}$ & $0.28(0.06) \mathrm{ab}$ & $4010(1232) a b$ \\
\hline Thinning and Burning & $0.38(0.07) \mathrm{a}$ & $0.47(0.09) \mathrm{a}$ & $7135(1820) \mathrm{a}$ \\
\hline$P$-value & $<0.001$ & $<0.001$ & 0.05 \\
\hline \multicolumn{4}{|l|}{ Red oak } \\
\hline Control & $0.18(0.04) b$ & $0.23(0.06) \mathrm{c}$ & $1493(327)$ \\
\hline Burn & $0.19(0.04) b$ & $0.26(0.05) b c$ & $2162(394)$ \\
\hline Thin & $0.35(0.07) \mathrm{ab}$ & $0.53(0.11) \mathrm{ab}$ & $2471(448)$ \\
\hline Thinning and Burning & $0.43(0.09) \mathrm{a}$ & $0.58(0.13) \mathrm{a}$ & $2420(485)$ \\
\hline$P$-value & $<0.001$ & $<0.001$ & 0.25 \\
\hline \multicolumn{4}{|l|}{ Hickory } \\
\hline Control & $0.12(0.02) b$ & $0.15(0.03) b$ & $2471(499)$ \\
\hline Burn & $0.21(0.04) b$ & $0.29(0.06) \mathrm{ab}$ & $3568(523)$ \\
\hline Thin & $0.37(0.05) \mathrm{a}$ & $0.44(0.06) \mathrm{a}$ & $4221(471)$ \\
\hline Thinning and Burning & $0.40(0.06) \mathrm{a}$ & $0.39(0.06) \mathrm{a}$ & $3346(502)$ \\
\hline$P$-value & $<0.001$ & 0.003 & 0.06 \\
\hline \multicolumn{4}{|l|}{ Sassafras } \\
\hline Control & $0.12(0.04)$ & $0.13(0.05)$ & $1905(758) b$ \\
\hline Burn & $0.24(0.06)$ & $0.29(0.08)$ & 5251 (1447) a \\
\hline Thin & $0.14(0.05)$ & $0.18(0.07)$ & $1133(416) b$ \\
\hline Thinning and Burning & $0.36(0.15)$ & $0.36(0.15)$ & $978(394) b$ \\
\hline$P$-value & 0.11 & 0.24 & $<0.001$ \\
\hline \multicolumn{4}{|l|}{ Other species } \\
\hline Control & $0.66(0.07) \mathrm{ab}$ & $0.80(0.09) \mathrm{ab}$ & $7465(660)$ \\
\hline Burn & $0.59(0.06) b$ & $0.64(0.06) b$ & $7310(565)$ \\
\hline Thin & $0.89(0.10) \mathrm{ab}$ & $1.03(0.11) \mathrm{a}$ & $7362(618)$ \\
\hline Thinning and Burning & $0.94(0.12) \mathrm{a}$ & $1.01(0.14) \mathrm{a}$ & 7619 (939) \\
\hline$P$-value & 0.01 & 0.001 & 0.98 \\
\hline
\end{tabular}

Means followed by same letters do not differ significantly $(P<0.05)$.

Table 3. Relative frequency, by species, of the tallest seedling classified as other.

\begin{tabular}{cccc}
\hline Species & $\begin{array}{c}\text { Relative } \\
\text { frequency }\end{array}$ & Species & $\begin{array}{c}\text { Relative } \\
\text { frequency }\end{array}$ \\
\hline Fraxinus spp. & 0.28 & Crataegus spp. & 0.03 \\
Ulmus spp. & 0.18 & Cornus florida & 0.02 \\
None & 0.12 & Acer negundo & 0.02 \\
Celtis occidentalis & 0.11 & Juniperus virginiana & 0.01 \\
Nyssa sylvatica & 0.07 & Morus spp. & 0.01 \\
Asimina triloba & 0.05 & Cercis canadensis & 0.01 \\
Prunus serotina & 0.05 & Acer saccharum & 0.01 \\
Ostrya virginiana & 0.04 & Elaeagnus umbellata & 0.01 \\
\hline
\end{tabular}


Differences in overstory density, but not in basal area, suggests the results of the thinning treatments remain consistent with commonly prescribed stewardship practices in this area; larger mean residual tree size in treated stands compared to uncut stands. Nevertheless, across all treatments stocking was still relatively high (Table 1), as was LAI, and it is likely that failure to continue active management within these stands would cause the treatment effects observed here to be fleeting as conditions improve for shade tolerant mesophytes relative to oaks and hickories. Although the treatments did not result in increased overstory residual growth [14], a future commercial timber sale is possible on these sites and intense cutting treatments may be required if a red oak component is desired, particularly on mesic sites $[19,20]$.

\section{Conclusions}

The results of the combined thinning and burning treatment support the use of a two-cut shelterwood system that is recommended to maintain an oak component in central hardwood stands [21,22]. The advanced oak regeneration component in this stewardship treatment has already begun to be distinguishable from untreated stands and would be presumably more responsive to subsequent overstory removal. In addition, the combined thinning and burning treatment should also result in stands that will be in a better position to withstand the impacts of an unintended overstory removal, such as a windstorm, which are relatively frequent in this region [23].

\section{Acknowledgments}

This project was funded by USDA Forest Service McIntire Stennis funds. We would like to thank Josh Nickelson and Nicole Jensen for assistance with data collection for this project. We would also like to thank four anonymous reviewers for their helpful comments with this manuscript.

\section{Author Contributions}

All authors contributed to study design, field work, analyses, and writing.

\section{Conflicts of Interest}

The authors declare no conflict of interest.

\section{References}

1. Abrams, M.D.; Nowacki, G.J. Historical variation in fire, oak recruitment, and post-logging accelerated succession in central Pennsylvania. Bull. Torrey Bot. Club 1992, 119, 19-28.

2. McEwan, R.W.; Dyer, J.M.; Pederson, N. Multiple interacting ecosystem drivers: Toward an encompassing hypothesis of oak forest dynamics across eastern North America. Ecography 2011, $34,244-256$.

3. Fralish, J.S.; McArdle, T.G. Forest dynamics across three century-length disturbance regimes in the Illinois Ozark Hills. Amer. Midl. Nat. 2009, 162, 418-449.

4. Nowacki, G.J.; Abrams, M.D. The demise of fire and "mesophication" of forests in the eastern United States. BioScience 2008, 58, 123-138. 
5. Holzmueller, E.J.; Groninger J.W.; Ruffner C.M.; Ozier, T.B. Composition of oak stands in the Illinois Ozark Hills two decades following light harvesting and no cutting. North. J. Appl. For. 2011, 28, 50-53.

6. Schweitzer, C.J.; Dey, D.C. Forest structure, composition and tree diversity response to a gradient of regeneration harvests in the mid-Cumberland Plateau escarpment region, USA. For. Ecol. Manag. 2011, 262, 1729-1741.

7. Hutchinson, T.F.; Long R.P.; Rebbeck J.; Sutherland, E.K.; Yaussy, D.A. Repeated prescribed fires alter gap-phase regeneration in mixed-oak forests. Can. J. For. Res. 2012, 42, 303-314.

8. Brose, P.H.; Dey, D.C.; Phillips, R.J.; Waldrop, T.A. A meta-analysis of the fire-oak hypothesis: Does prescribed burning promote oak reproduction in eastern North America? For. Sci. 2013, 59, 322-334.

9. Riechman, J.A.; Park, L.; Ruffner, C.M.; Groninger, J.W. Challenges and motivations behind sustaining a volunteer-based forest management organization: A case study of the southeastern Illinois Prescribed Burn Association. J. For. 2014, 112, 215-220.

10. Ruffner, C.M.; Groninger, J.W. Making the case for fire in southern Illinois forests. J. For. 2006, 104, 78-83.

11. Iverson, L.R.; Peters, M.P.; Prasad, A.M.; Hutchinson, T.F. Thinning, fire, and oak regeneration across a heterogeneous landscape in the eastern US: 7-year results. For. Ecol. Manag. 2008, 255, 3035-3050.

12. Hutchinson, T.F.; Sutherland E.K.; Yaussy, D.A. Effects of repeated prescribed fires on the structure, composition, and regeneration of mixed-oak forests in Ohio. For. Ecol. Manag. 2005, 218, 210-228.

13. Carril, D.F. Effects of repeated prescribed fire and thinning from below on understory components of southern Illinois oak-hickory forests. Master's Thesis, Southern Illinois University, Carbondale, IL, USA, 9 August 2009; p. 104.

14. Anderson, M.; Holzmueller, E.J.; Ruffner, C.M.; Groninger, J.W. Growth Response of Mature Oaks Following TSI and Prescribed Burning Treatments. In Proceeding of 4th Annual Fire in Eastern Oak Forests Conference, General Technical Report NRS-P-102; USDA Forest Service: Newtown Square, PA, USA, 2012.

15. Gingrich, S.F. Stocking, Growth, and Yield of Oaks Stands P 65-73. In Oak Symposium; USDA, Forest Service: Upper Darby, PA, USA, 1971.

16. Blankenship, B.A.; Arthur, M.A. Stand structure over 9 years in burned and fire-excluded oak stands on the Cumberland Plateau, Kentucky. For Ecol. Manag. 2009, 225, 134-145.

17. Dey, D.C.; Hartman, G. Returning fire to Ozark Highland forest ecosystems: Effects on advance regeneration. For. Ecol. Manag. 2005, 217, 37-53.

18. Sander, I.L.; Johnson, P.S.; Rogers, R. Evaluating Oak Advance Reproduction in the Missouri Ozarks; USDA Forest Service: St. Paul, MN, USA, 1984; p. 16.

19. Kabrick, J.M.; Zenner, E.K.; Dey, D.C.; Gwacze, D.; Jensen, R.G. Using ecological land types to examine landscape-scale oak regeneration dynamics. For. Ecol. Manag. 2008, 255, 3051-3062.

20. Rebbeck, J.; Gottschalk, K.; Scherzer, A. Do chestnut, northern red, and white oak germinant seedlings respond similarly to light treatments? Growth and biomass. Can. J. For. Res. 2011, 41, 2219-2230. 
21. Brose, P.H. Root development of acorn-origin oak seedlings in shelterwood stands on the Appalachian Plateau northern Pennsylvania: 4-Year results. For. Ecol. Manag. 2008, 255, 3374-3381.

22. Brose, P.H. A comparison of the effects of different shelterwood harvest methods on the survival and growth of acorn-origin oak seedlings. Can. J. For. Res. 2011, 41, 2359-2374.

23. Holzmueller, E.J.; Gibson, D.J.; Suchecki, P.F. Accelerated succession following an intense wind storm in an oak-dominated forest. For. Ecol. Manag. 2012, 279, 141-146.

(C) 2014 by the authors; licensee MDPI, Basel, Switzerland. This article is an open access article distributed under the terms and conditions of the Creative Commons Attribution license (http://creativecommons.org/licenses/by/4.0/). 